\title{
Political Crisis and Institutional Resilience: Conditional Cash Transfers under Scrutiny in Brazil and Philippines*
}

\author{
MARK STEVENSON CURRY**
}

\begin{abstract}
Extraordinary political transitions in 2016 in two middle-income developing countries, Brazil and the Philippines, may adversely affect efforts to reduce poverty and gender/social inequalities through Conditional Cash Transfers ('CCTs'). This paper investigates institutional conditions governing CCTs in these two countries and reflects on the potential impacts of policy incursions. The proposition here is that sound developmental programmes can produce broad and compelling within-institution influences as well as causal cross-institution linkages in other domains. New and quickly successful programmes can also be targets for policy assaults and subversions. How resilient are social protection institutions like CCTs to political shocks? Applying Levitsky and Way's (2015) concept of timing and sequencing in authoritarian regime durability to the question of institutional resilience, this comparative-historical case study aims to examine three issues: the processes traced by CCT evolution that in each case relate to institutional resilience, the factors contributing to policy shocks, and the resilience of CCTs in response to seismic macro-political change. The approach takes varieties of knowledge as a valuable alternative to neoliberal structures of domination and contributes to the important and urgent need to understand social protection institutions as human development resources of variable durability.
\end{abstract}

Keywords: Conditional Cash Transfers, Brazil, Philippines, Institutions, Resilience, Policy Shocks

* The author would like to thank Dr Su-Ming Khoo, Mikyung Park, and Louie Montemar for input, discussion, and suggestions. Any shortcomings are the author's responsibility.

** Ph.D. Candidate, NUI Galway, Ireland;E-mail: m.curry3@nuigalway.ie DOI: 10.16934/isr.18.2.201712.59 


\section{INTRODUCTION}

Conditional Cash Transfers ('CCTs') provide targeted poor families with regular cash grants while reciprocally ensuring e.g. that children attend school and get vaccinated, and pregnant women receive health check-ups. Brazil and Mexico respectively introduced this kind of intervention in pilot projects in the mid-1990s to overcome the deleterious effects of early neoliberal World Bank and IMF Structural Adjustment Programmes ('SAPs') from the 1980s. They have since been exported to over 50 developing countries with the administrative and technical support of international institutions like the World Bank. The Philippines derived its CCT model under such tutelage from the Latin American programmes. Although popular among beneficiaries, policymakers and donorfunded researchers, in Brazil and the Philippines these programmes have come under simultaneous, uncoordinated challenge by adversarial political actors, particularly since the respective 2016 elections in each country. How resilient, then, are social protection programmes like CCTs in the context of endogenous political shock? To address this question, it is necessary to comparatively trace the processes that evolved into the respective institutional conditions these CCTs currently operate in and to examine the factors related to the political challenges that CCT policymaking and administration face.

The paper begins with the observation that the CCTs of Brazil and the Philippines were introduced to ostensibly reduce poverty and inequalities under democratic norms. However, the respective political changes in Brazil and the Philippines have fundamentally changed the macro political context in which such social protection programmes must operate: Rodrigo Duterte became the Philippines' $16^{\text {th }}$ president on 30 June 2016, which re-introduced neo-authoritarian populism for the first time since the 'EDSA' pro-democracy movement removed Ferdinand Marcos in 1986. Two months later a palace coup in Brazil ousted Dilma Rousseff and installed Michel Temer as unelected caretaker president. Scholarship into social policy programme effectiveness typically excludes macro political fluctuations while institutional analysis at the macro level is not concerned with outcomes at the programme level. A contribution of this paper to social development thus lies in the attempt to bridge these two spheres by a comparative examination of CCTs at the cusp of political and policy changes.

The process of the paper is as follows: the next section reviews the CCT scholarly research, followed by a methodology section. The fourth section outlines the comparative-historical context for CCT initiatives in Brazil and the Philippines, including the basis for comparison and the political shifts of 2016. The paper then outlines and discusses the origins, processes and timing of CCTs. The sixth section concludes the paper. 


\section{LITERATURE REVIEW}

Since the advent of CCTs in Mexico and Brazil in the mid-1990s, research in this social protection arena has burgeoned. Mkandawire (2001) linked policy orientation of the kind that incorporates CCTs to the 'rediscovery' of poverty, a critique that encompassed the social and economic fallout from Structural Adjustment Programmes ('SAPs') and the policy dogma that limited poverty reduction to economic growth factors. From within the World Bank's structures, Steven Tabor (2002) affirmed such reorientation by endorsing cash transfers on the rationales of sound economic sense, as a means of addressing complex issues like gender discrimination, and focussing social risk management innovations. By the mid-2000s, Anthony Hall (2007) had situated cash transfers at the core of social protection policies at the World Bank. However, in opposition to the proliferation of the Bank's official Social Protection Paradigm ('SPP'), particularly in Africa, Jimi Adesina (2010) argued against full-spectrum aggressive policy salesmanship in favour of a transformative concept of social protection that in a multi-faceted way accommodated local culture and community development. Yet, from an institutional analytical perspective, the UNDP's (2013) Human Development Report hailed the 'Rise of the South' and acknowledged the contribution CCTs had made in achieving poverty reduction objectives. In short, the literature on CCTs broadly splits into two contested discourses: global institutions at work to develop the universal value of CCTs posited against critical voices that utilise anthropological and historical perspectives. The review assesses each discourse in turn.

CCT literature funded by International Financial Institution ('IFI') donor/ lenders such as the World Bank or Asian Development Bank uses high quality datasets to focus on programme design and implementation, metrics and indicators, monitoring and evaluation, and outcomes such as behavioural change, enrolment, nutrition, and poverty reduction. The aim, ultimately, is towards rolling out new programmes or adapting existing ones. The work e.g. of Bourguignon et al (2003), among others, exemplifies the approach. Fiszbein and Schady's (2009) comprehensive account, compiled during the financial crisis, covers the global CCT field in detail with findings that generally affirm the importance, success and desirability of well managed and well targeted CCTs.

In the Brazilian CCT arena, literature that accords with the above categorisation includes work of Soares (2012), among others. Since CCTs in the Philippines incorporated IFI inputs at the pilot stage, positive impact findings are presented e.g. in work of Fernandez and Olfindo (2011) and Acosta and Velarde (2015). As such, this stream of knowledge differs from Enrique Lomelí's (2008) observation that the Latin American CCT theatre was prone to funnelled thinking, which needed to be redirected towards an expansionist focus, one that integrated 
varieties of social programme towards citizenship and community ideals, an insight that corresponds well with Adesina's (2010).

The above body of research presents problems not simply related to minimalist tendencies and instrumentality. It presents CCTs as a field with a truncated history. For example, a recent World Bank research briefer states that CCTs were developed "as part of larger efforts to make safety nets more effective, replace badly targeted subsidies, or integrate smaller programs" (World Bank 2016, n.p.). This claim elides IFI policy-making of the SAP era that wrecked developing country economies, thus necessitating CCTs in the first place, and elides from the record the significance in Brazil's case of cash transfers as having originally been mooted as an unconditional initiative (Soares 2012). This dissonance in the basic description of the field thus leads to an alternative branch of CCT literature.

Critical CCT studies examine programme design, targeting and outcomes against specific criteria, such as the role of women. A formidable body of research from fieldwork through longstanding relations in non-metropolitan communities has shown that CCTs, in the nominal interest of women's development, add hours of unpaid labour, increase burdens and responsibilities without access to the stipulated benefits, and reincorporate women within existing or traditional paradigms of patriarchal power (see e.g. Molyneaux 2006; Cookson 2016). Sarah Bradshaw (2008a) argues the links between the negative impacts of SAPs and the 'social adjustment' impositions of CCTs on beneficiaries by which the poor are adversely incorporated into asymmetrical relations regarding their input to the economy: the IFI's SPP thus acts as a foil for a reinvigorated economic growth platform. This body of knowledge utilises historical and anthropological methodologies, two areas that are rich in data, but which elude governance by the "power of numbers" (Fukuda-Parr et al 2014, 105), the vehicle of purpose for IFI-funded CCT research.

Few studies, however, provide analyses of CCTs in relation to institutional actors. Bradshaw (2008b) configures CCTs within the agency dynamics of religion, banking, and the state to equate neoliberal policy prescriptions with conservative attitudes governing gender norms, and women's rights and bodies. Ben Reid (2016) from a different perspective takes issue with the social risk management position outlined of Tabor's (2002) account to argue that countries like the Philippines have not only adopted a neostructuralist CCT model that marries neoliberal prerogatives with minimum incomes, but one that dispenses with constitutional rights into the bargain. More particularly, the state's compliance-based CCT apparatus produces ample data on the poor while maintaining the structural causes of poverty.

To draw these streams of knowledge together, critical analyses of CCTs focus on political parameters while more minimalist studies that find favour in 
CCT outcomes and prospects remain within the purview of sociology. What these bodies of knowledge as reviewed above do not anticipate or account for is the sudden, drastic political changes that took place in 2016 in Brazil and the Philippines, a sea change of fundamental importance to the future of cash transfer programmes in general, and to the democratic values subtending them.

A gap in the literature that this paper seeks to address derives from the observation that macro political change generally lies outside the ambit of sociological inquiry, given its focus on such areas as programme effectiveness. Meanwhile, advances in comparative analysis in political science, as reviewed by Mahoney and Thelen (2015), necessarily bypass social protection institutions. Where, for example, Haggard and Kaufman (2008) cover social welfare regimes in developing countries globally, their work excludes CCTs and policy effectiveness on questions, for example, of gender equality. This paper aims to bring a political science approach into the domain of sociological inquiry regarding CCTs. By means of comparative-historical analysis, the overriding question this entails is how resilient are social protection policies and programmes in the context of endogenous political shocks?

\section{METHODOLOGY}

Levitsky and Way (2015) use a comparative-historical analysis to explain the durability of authoritarian regimes following shocks such as economic crises. They observe that "timing and context" - 'when' and 'how' constraintscontribute to the usefulness of the method in explaining aberrant phenomena in contemporary politics, such as the longevity of brutal regimes $(2015,98)$. In this study, we adjust the scale and reverse the modality of analysis: we want to establish an understanding of how political change in 2016 represents a shock to the legacy of institutions responsible for social protection in both Brazil and the Philippines. How resilient are these institutions to sudden political change or policy reversals?

We can address this question by looking at when and how the CCT environment evolved in the context of other social protection and political institutions. The complementary analysis involves comparatively examining when and how new political actors stage policy intrusions on social protection institutions. To further adapt Levitsky and Way (2015), a bigger problem facing scholars and practitioners in CCTs and poverty/inequalities reduction concerns the boundedness of programmes, policies and institutions. Boundedness is used here to refer to limits, buffers or 'skin'. In the worst case, a sound social protection legacy dissipates or implodes, even in the absence of external challenges. The 'skin' in this sense is porous to outside influence, decays readily or is too calcified to prevent collapse. In the best-case scenario, a strong programme, policy or 
institution produces dynamic effects that are generated endogenously.

Such effects can be transmitted both within and across institutions, generating further influences that feed back to fortify the institution over time. The 'skin' in this case needs to be resilient yet adaptive. The relevance of the idea of boundedness to this paper is that CCTs under IFI tutelage and promotion had promised to establish a best-case institutional legacy. Certainly, recent reports of the World Bank (e.g. Acosta and Velarde 2015) and the UNDP (2015) relied on this assumption. Sergei Soares (2012) went so far as to propose how Bolsa Família ('BFP') in Brazil could be recalibrated under Dilma Roussef to eradicate poverty altogether. Instead, Roussef has been ousted and BFP has been scaled back with social payments frozen for two decades. Against such policy assaults, the political process, beneficiary experience, scholarly evidence and social movement voice have appeared powerless. The Philippine case since 2016 differs in the sense that President Duterte has vacillated on CCT policy-making: promises to extend CCT benefits have been countered by violent police action against the poor and a failure to support his own nominee as head of social protection, while enjoying the support of political actors like Senator Marcos who espouse abolition of the CCT programme. An assessment of the problem of political shocks and institutional resilience in the social protection arena is therefore directly required.

\section{THE SOCIAL PROTECTION CONTEXTS: BRAZIL AND PHILIPPINES}

This section outlines the basis for comparison between Brazil and the Philippines and traces the processes in the relevant literature to situate CCTs within the social protection contexts of each case. We also identify new challenges to CCT resilience since the 2016 elections.

Despite differences of geography, language and political-historical experience between Brazil and the Philippines, useful commonalities can be identified for bases of comparison in the social protection arena. Both countries share a separate but prolonged identity as colonies of Iberian European powers, Portugal and Spain, at the heights of their respective imperial prowess. Each was invested by regalian decree with rights to property and primitive accumulation that generated vast, permanent inequalities. Settlers and immigrants accrued the wealth; the indigenous (and African slaves in Brazil) were sequestered from power and opportunity by law, education and institutional force. Each country has been sustained until the present by the cultural and ideological influence of the Catholic Church (see e.g. Assunção 2006; Bello 2009).

Moreover, each country achieved notional political independence but quickly became subsumed into the world-system of states in core-periphery relations with the world-colonizing states of Europe and North America up until 
World War Two. They experienced cyclical commodity booms, which thrust them into temporarily favoured semi-peripheral status. Each experimented with Import-Substitution Industrialization as a means of development outside the constraints imposed by the world trade regime (Haggard and Kaufman 2008). Socially, inequality was entrenched with opportunities for advancement limited to elites and aspirant middle classes.

In the widespread autocratic shift in the latter half of the 20th Century, both countries experienced roughly synchronous military/militaristic dictatorships of about two decades. In Brazil, the military regime lasted from April 1964 to March 1985; in the Philippines, the Marcos era began in 1965, pivoted to martial law in 1972, and collapsed in 1986 (Bello 2009). After the advent of democratic norms that enshrined constitutional rights for all citizens, each country then underwent radical economic and social restructuring in the 1980s and 1990s at the behest of IFIs under SAP bailout schemes.

Having established the grounds for comparison between the two cases, the SAP era requires further comparative elaboration because it is fundamental to an understanding of the politics underlying CCT origins and innovations.

SAPs were macroeconomic reforms to enable medium-term opportunities for development. In principle, loans to borrower nations came tied with instruments in pursuit of economic growth such as deregulation, flexible exchange rates, privatisation, reduced labour protections, public expenditure reductions, and free movement of capital (Williamson 1993). In practice, new IFI loans at runaway rates of interest gave rise to capital flight. In a fiscal sense, these loans were tough macro-scale conditional cash transfers that punished the poorest sectors of society by imposing the downstream removal of social benefits and job security (Britto 2005). The Philippines had received ten SAP bailouts by 1998, the year that Brazil underwent a severe IFI-imposed SAP intervention. In a socio-economic sense, SAPs compounded the adverse and unfree political conditions that had been survived only years previously under the dictatorships.

If SAPs were instruments to free the market of state constraints, then CCTs evolved in response to the widespread social devastations and income gaps caused by market failure. The originating aims of the first comprehensive CCT programme-Mexico's PROGRESA, which started in 1997-were to intervene at the immediate level of extreme poverty by providing subsistence grants, and to derail long-term poverty cycles through health and education requirements for children. The IFI rediscovery of social protection has meant that since 1997 CCT implementation worldwide invariably involves IFI finance and technical assistance (Fiszbein and Schady 2009).

We now need first to consider the specific context regarding the timing and sequencing of the Brazilian and Philippine CCT programmes, respectively, within a comparative-historical examination of the respective social security 
institutions.

Brazil's social protection model traces its origins to the European welfare state model where social policy's purpose was to alleviate damage to society from cyclical market failures and to bolster income security through the public purse. Haggard and Kaufman (2008) elaborate on features of the Brazilian model that contrast in interesting ways with the Philippine social protection experience. First, the Getúlio Vargas dictatorship introduced social protection between the 1930s and 1940s to divide loyal and oppositional working-class groups. Pressure to expand coverage was suppressed because there was no electoral contestation (Haggard and Kaufman 2008, 98-99). In subsequent decades, the split between landed oligarchs and urban workers intensified political crises without affecting the structure of social security or broadening the distribution of benefits: changes to the pension scheme merely improved the lot of those already included in it. Moreover, rural school enrolment until the 1950s remained extremely low. Literacy and property ownership restrictions on voting meant that landed oligarchs had no incentive to risk changing rural power relations over landless peasants by permitting them an education (99-100), a model of development that demonstrated durable utility in transferring benefits from the poor to the rich.

Second, the catalyst for change to the welfare model did not come from the left but from the hard right under military dictatorship from 1964 to 1985 . By 1980, pensions for the rural poor and basic health insurance reached less than 10 percent of the population (Haggard and Kaufman 2008). In addition, higher education was prioritised over elementary education as a means of placating urban middle-class interests and keeping rural populations in traditional clientelistic relations with respect to the landed oligarchs. Such redistribution as existed was tied to patronage politics and corporate interests, i.e. construction budgets for schools and private sector hospitals (102). Serious structural change only began in the democratic era in the mid- to late 1980s, which coincided with the advent of exogenous macro-economic contraints in the form of SAPs.

As in the Brazilian case, the Philippine concept of social protection services centred on three elements: patronage politics, fostering rural-urban cleavage, and as a means of keeping the forces of the left wing fragmented. The organisation and development of services was essentially conservative and top-down (Haggard and Kaufman 2008, 117-121). In practice, welfare service priorities oscillated from rural insurgency hot-spots to urban industrial situations, and increased or decreased corresponding to the electoral cycle. In a notable divergence between the cases, the Philippines took its social protection policy models from the US. These were initiated in scale under President Ramon Magsaysay between 1954 and 1957-much later than in Brazil-in response to a rural guerrilla insurgency. Moreover, until Martial Law in 1972 they evolved in a relatively lively, competitive electoral environment. While both Brazil and the 
Philippines figured in US Cold War-era strategies, the US had since colonial times been directly invested in Philippine institutions like education. Indeed, the Philippines mobilised the roll out of welfare initiatives, such as its Social Security System, quickly and broadly (Haggard and Kaufman 2008, 121; 240). A significant difference in the two cases resides in characteristics of the Marcos dictatorship years. Cronyism, plunder and the redirection of social service funds into private hands made the Marcos era a "regression in terms of social policy, poverty, and inequality" (123).

In comparison with the Philippines, Brazil gives evidence of being a first mover in institutionalizing social initiatives but slower to produce well-ordered, comprehensive rollout. Also, Brazil's two major periods of dictatorship made the provision and extension of some social services, like the old age pension, more direct and effective than was possible under the stalemates produced during competitive electoral processes. Nevertheless, the 'push-pull' characteristic of the Brazilian political process presents evidence of structural ideological conflict, shifts and stand-offs. By contrast, presidential control in the Philippines since independence until Rodrigo Duterte in 2016 has primarily involved elite Manila families with strong ties to the rural oligarchs, while the Philippine dictatorship era withered, subverted or plundered social institutions. In both institutional settings, the timing and sequence for real change from the middle and bottom arrived in the mid-1980s with the democratic turn.

The near-synchronous advent of democracy in both countries ushered in new constitutions that for the first time codified and established the rights of all citizens and the state's requisite responsibilities towards them. The Philippine constitution was ratified into law on $15^{\text {th }}$ February 1987, relatively soon after Marcos's exile, whereas after a two-year deliberative and drafting process, Brazil's constitution was announced publicly on $5^{\text {th }}$ October 1988 . These respective milestones created structure and agency for the provision of social services and protections to all citizens. Codifying and publishing these constitutions within a year of each other reflects the demand for fundamental change and the mobilisation of human, legislative and political resources to ensure it. The major difference is that in Brazil the constitution created agency for decentralized decision-making, budgeting and social service provision, which in turn was specifically utilized to spear-head CCT implementation (Britto 2005). In the Philippines, on the other hand, there is no indication that constitutional provisions played any part in promoting CCT development. Instead, Millennium Development Goals ('MDG') exigencies and the problem of President Gloria Macapagal Arroyo's legacy may have been more fundamental rationales for the expansion of social protection between 2007 and 2009 (DSWD 2009).

Struggles to emerge from oppression leave many complex residues. Whereas both dictatorships had to different degrees used social policy and social 
services to reward collaborators, cronies and useful strata in society, the subsequent SAP era pushed middle classes into poverty and left the middle classes poor and the poorest deciles of the population floundering. Curiously, CCTs as a method of generating recovery from the impact of pernicious policies emerge with residue of the very oppressiveness they were meant to overcome, as Reid (2016) elaborates. These constraints have been amplified since 2016. The elite seizure of power in Brazil and the election in the Philippines of a provincial warlord threatens in quite different ways to resume the SAP era assault on social and human development, this time endogenously rather than exogenously.

CCTs have been controversial in both Brazil and the Philippines and critiqued on several fronts. Whereas the post-SAP World Bank is an enthusiastic promoter of CCT programmes (e.g. Acosta and Velarde 2015), Britto (2005) warns that CCTs are not a royal route to development. Other critics like Bradshaw (2008a; 2008b) see IFI engagement in CCT rollouts as a strategy of incorporating social policies into the fold of neoliberal interests rather than acknowledging and addressing the structural flaws of neoliberalism itself.

In the Philippines, the far-left never favoured the Pantawid programme. They rejected the 'dole' perception of the transfer and the patronage problems associated with how particular exclusions from beneficiary status occurred. Instead, they espouse social funding for creating meaningful jobs in home-grown industries and argue for repealing CCT provisions (Sauler 2016). In Brazil, by May 2016 one of Michael Temer's first moves was to curtail BFP, and over a million beneficiaries have since been delisted from the registry (Branco 2016). Moreover, in December 2016, Temer's elite, male cabinet directed a spending cap called PECC 55 that imposes a 20-year austerity plan, described by UN officials as one of the world's most pernicious (Phillips 2016). This highlights CCT vulnerability within the overall power politics arena. Any successes and all problems related to CCTs have made them accessible political targets.

\section{ORIGINS, TIMING AND SEQUENCING OF HOW CCTS WORK}

Social protection evolves over time via debates over questions of unconditionality, universality, technical distribution, amount, programme graduation and exogenous shocks. Timing and sequencing of cause and agency also play a role in determining the meaning, value, and durability of the institution. Up until 2016, Brazil's BFP reached some 55 million people, about 25 percent of the population (Silva 2014). Since its inception, BFP has been the political preserve of the centre-left faction of the Workers' Party, one reason for the programme being targeted by political opponents in Brazil's congress, despite the programme costing as little as 0.5 percent of GDP per annum (Soares 2012; Silva 2014). In this section, we examine BFP's origins, timing and sequencing in situ and in 
relation to the establishment of the Pantawid (4Ps) CCT in the Philippines.

Three years after the promulgation of Brazil's 1988 constitution, a broad-based left-wing coalition brought social protection and the constitutional framework to the congressional floor in Brasília. This gave agency to an unconditional cash transfer initiative tabled in 1991 by Senator Eduardo Suplicy, which became transformed into a pilot conditional cash transfer programme from 1995 in Brasilia as well as in the Sao Paulo region (Soares 2012). The nationwide rollout from 2000 under President Fernando Henrique Cardoso's second term was a policy shift away from the structural reform neoliberalism of his first term in office between 1994 and 1998. The menu of CCT programmes included subsidies for school attendees, nutrition for children and new mothers, basic sustenance, and cooking oil. These programmes were fragmented, administratively obtuse, organised, financed inchoately and for conflicting goals, and contested from both the harder wings of the left and the right (Soares 2012; Haggard and Kaufman 2008, 284-5; Curry et al 2013).

In 2003, Luiz Inácio Lula da Silva ('Lula'), a former factory labourer and founder member of the Worker's Party, took over the country's presidency to popular acclaim and market insecurity. His policy approach, however, was towards conciliation and stability, which increased tensions within his core support networks from those who wanted quick, radical change (Haggard and Kaufman 2008, 283). In the social protection arena, Lula directly consolidated the four component programmes into BFP. Centralized programmes enabled coverage to expand and indirectly achieved a less visible aim of marginalizing the far-left groups that had spearheaded universal social protection from the beginning (see e.g. Silva 2014).

BFP's technical workings have been covered in detail elsewhere (see Soares 2012) and need not detain us here except to note the following critiques. Beneficiary non-compliance with conditionalities invokes a series of warnings, frozen payments, and registry disbarment. For Maria Silva (2014), among others, these penalties are instruments of conservative, morality-based and anti-poor thinking that contravene the spirit and letter of the citizens' constitutional rights. Whereas in Brazil political conservatives insisted against a dole-type unconditional cash transfer, in the Philippine case it is the far left that strongly disavows dole pay-outs.

Several factors related to the how and when of BFP implementation are important here. First, Lula da Silva's consolidation of social protection services into BFP in 2003 side-lined the hard left, which may have robbed Dilma Roussef of support as elite conservative pressure grew against her from 2015. Second, the BFP system is relatively simple in principle but extraordinarily complex in its finer details, particularly where questions of equivalent circumstances or non-compliance are concerned. Third, Brazilian social welfare outcomes are still equivocal: 
absolute poverty is down, maternal and child health indices have improved, but employment uptake among CCT beneficiaries remains intractably low, especially in the North-east of Brazil. In other words, inequalities remain stubbornly entrenched, which puts within- and cross-institutional pressures on the programme. Fourth, the federal adoption of BFP for national implementation in 2003 brought the World Bank back in, which in Brazil's experience has tended to be associated with macro-economic troubles downstream. Fifth, countries that adopted the Brazilian model drew in part on Brazil's reputation for success as designated host to major sporting events like FIFA's World Cup and the IOC's Olympic Games in quick succession. The roles of Petrobras and Odebrecht in one of the most profound corruption scandals ('Operation Lava Jato') in the country's history were however unknown at the time. Much more knowable is Brazil's history of dictatorship and ideological contestation, systemic seizures and fiscal meltdowns, and its social and political gyrations between progressive activism and reactionary backlashes along a rural-urban divide that remains intractable. Can an export model of social protection stand apart from macro-political malfeasance? Finally, a question of bifurcations remains. Brazil's achievements have fuelled moves to introduce a Universal Basic Income (UBI) system of unconditional benefits for all citizens in several rich world countries, including Finland and in the Netherlands. Whether BFP's trajectory take this direction or witnesses its notionally pro-poor appurtenances become retrenched in the future as Brazil develops along rich world standards of living remains to be seen, but evidently Michel Temer's holdover government has no intention of allowing a UBI model to evolve.

The Philippine Pantawid CCT programme differs from its Brazilian model in that it was first implemented in late 2007, four years after the amalgamation of Brazil's various social protection schemes into BFP. Its initial ambitions owed more to Millennium Development Goal compliance by 2015 than with constitutionally enshrined citizenship rights. Pantawid ('4Ps') began as six small-scale pilot projects in rural and urban settings before quickly being scaled up to meet applicant-beneficiary demand and electoral cycle prerogatives (Curry et al 2013). It has featured in the policy-making of three presidents (Arroyo; Aquino; Duterte) with respectively different constituency support platforms and different policy prerogatives, domestically and internationally. Since 2014, Pantawid has also prioritised single-parent homes and women as head of household, while including gender sensitivity training and gender equality for male and female enrolees (Engracia 2015).

However, Pantawid resembles BFP in its use of a targeted (proxy meanstested) beneficiary approach, a conditions-compliancy component, a national database for keeping records and monitoring the system, and delisting for non-compliance. Technically, it is supposed to be free of interference from regional 
officials and municipal captains. However, in the Philippines this is difficult to secure and monitor, particularly at election times (Swamy 2016). It is also not a stand-alone programme: although Pantawid has accounted for over 50 percent of the DSWD budget since 2011 (Fernandez and Olfindo 2011), the department is responsible for other welfare programmes such as Kalahi-Comprehensive and Integrated Delivery of Social Services ('Kalahi-CIDSS'). Nevertheless, its overall budgetary allocation at an average of PHP 60 billion between 2012 and 2016 brings its cost to GDP to approximately 0.4 percent, which is comparable to the Brazilian case.

The DSWD was made responsible for Pantawid's design and implementation during the presidency of Gloria Arroyo. In theory, the aim of the scheme was to break long-term poverty cycles and to set a floor beneath those in absolute poverty, following Latin American models. In practice, the DSWD's structures, orientation and administration needed reform, the 1997-1998 Asian financial crisis had brought the World Bank back into social protection to overhaul IFI reputations, and the 2008 global economic crisis spurred action (Fernandez and Olfindo 2011; DSWD 2009). Arguably, Gloria Arroyo also acted decisively on social protection to secure her presidential legacy. This included trying to assure a path for her chosen successor in the 2010 elections, compounded by her impending prosecution for allegations of a variety of acts and levels of plunder, corruption and graft.

The basics of the Pantawid implementation process and technical workings are well known (see DSWD 2009; DSWD 2013) and need not be covered here except to note that the system has not always worked to plan. Reyes (2017) reported disbursement delays of more than 12 months because of banking administrative bottlenecks and a failure to secure adequate partnerships with conduit financial agencies in the most rural areas.

Other problems and anomalies related to the rapidly scaled up implementation of Pantawid deserve to be highlighted despite the programme's relatively straightforward and clear administrative set-up. First, Reyes and Tabuga (2012) argue that the Philippines incurred debts from the beginning by borrowing US $\$ 805$ million from the World Bank to guarantee funding for the programme. They also note that getting reliable data from the extreme south of the country is difficult (and, subsequently, dangerous owing to insurgency and militarisation in the region, especially given the open conflict in Marawi since May, 2017). In addition, facilities are not fit for purpose, electricity is intermittent and communications weak, which makes compliance procedures difficult.

A second anomaly is that DSWD (2009) stipulated a budget between 2010 and 2014 of PHP 10.8 billion. However, by 2013, the DSWD $(2013,3)$ claimed disbursements of PHP 6.908 billion as having reached 104 percent of its target beneficiary household. This suggests a serious budgetary discrepancy quite apart 
from scaling errors. For example, according to the Philippine Department of Budget and Management ('DBM'), in 2016 Pantawid's portion of the DSWD budget share was approximately PHP 62.7 billion, in itself a sum six times greater than the entire DSWD budget for 2009. The 2016 budget included a 'cost of finance' item. At PHP 781 million ( 0.8 percent of the budget total), this was nevertheless 2.6 times more than the entire budget appropriation for Pantawid in 2008 (DBM 2016).

Third, actual outcomes appeared sticky and resistant to change from benchmark levels. For example, DSWD (2009) data suggested that beneficiaries were pleased and that evaluation proved the efficacy of the programme. However, Balamban et al (2013) showed that between 2006 and 2012 poverty levels had only reduced from 28.8 percent of the total population to 27.9 percent while over the same period inequality had diminished by a mere 0.8 percent (from $14.2 \%$ to $13.4 \%$ ). This critique has support from budgetary data: whereas CCT budgets accelerated rapidly, comparative allocations to the departments of Health and Education did not suggest that complementary facilities, materials, access and opportunities to services were improving over the same period. In other words, compliance terms remained the problem of the beneficiary rather than the responsibility of the state (Curry 2014).

We can now directly characterise the evolution of CCTs in Brazil and the Philippines. First, in Brazil, Lula's charismatic leadership and his post-electoral assurances to international lenders/investors of macro-economic continuity from the Cardoso era made it possible to amalgamate and expand BFP. If BFP had successfully reduced both poverty and inequalities, its beneficiaries could have been expected to protest in favour of the programme, or its political guardianship, or both: 55 million beneficiaries presents in theory a formidible constituency. However, CCTs do not constitute a social movement, as Dilma Rousseff, Lula's less charismatic successor, discovered. Increased public spending on BFP, including a 9 percent increase in benefits, did nothing to prevent her removal from power (Economist 2016). In other words, BFP's achievements and its victories for centre-left policy development of the Global South appear somewhat Pyhrric: a minority of elite conservatives buckled the programme's resilience and used it as the focal point in debates over the state's problems with corruption and macro-economic incontinence. BFP's 'skin', to refer to a concept elaborated in the methodolgy section, appears to have been provisionally irrelevant rather than too brittle or too porous.

Second, although BFP was rights-based in its conceptual origins, the political actions needed to turn it into structure with agency created fractures for Lula within his own party in three ways. First, Lula marginalised the radical thinkers of the Workers' Party. Second, he promoted a conditional rather than an un-conditional cash transfer platform even while cutting social spending by US\$ 
2 billion in the first two years of his presidency to satisfy IMF spending targets, compounding problems in the supply of services in BFP-related sectors such as housing, sanitation and education. Third, he maintained continuity with unpopular Cardoso-era policies despite having campaigned to eliminate them (Hunter and Power 2005; Soares 2012; Hall 2008). The BFP edifice thus arose at the expense of the peoples- and rights-based initiative that ostensibly founded it. This offers the observation that the resilience of a pro-rights institution is eroded of power if in its evolution the institution detaches from the people it is meant to support. In other words, the pro-poor social platform that the Workers' Party built up with notable regional successes in the lead up to Lula's election not only proved difficult to institute at the national level but generated fragmentation within the party itself (Hunter and Power 2005). The institution's 'skin' or boundedness was not the problem, rather the way the institution itself divided its proponents.

Third, the process traced by BFP as an institution reflects aspects of land reform history in Brazil. The latter is a 'pushme-pullyou' tug-of-war between entrenched ideological factions: the landless against landed oligarchs. Gains over time by the Movimento dos Trabalhadores Sem Terra, the Landless Workers' Movement ('MST'), incur waves of resistance. Since the rise of Temer and the militaristic Bolsonaro faction, landgrabbing, assassination, illegal incursions into protected areas, and assaults on landless people's organisations have increased (Campbell 2017). MST's success in occupying and distributing idle land to peasant farmers has involved important factors, including leadership, organisation, group integrity, effective communications, timing and sequence of land occupations, and the macro-political environment stemming from both the 1988 Constitution's provisions and the electoral strength of Lula da Silva's Workers' Party. However, both provisions have proved incapable either of stopping the Temer insurgency or maintaining the resilience of pro-poor institutions.

The point to be registered here follows the methodological specifics of this paper. BFP as a social protection institution in Brazil highlights two related characteristics. First, from 1991 to 2016 BFP exhibits internal (within-institutional) push-and-pull rhythms in its transition from an unconditional to a conditional programme, and from small scale and piece-meal pilot projects to nation-wide rollout on a programme basis. Secondly, BFP plays a push-and-pull role in the broader (cross-institutional) power-politics arena, from domestic, party-political policy making to MLO/IFI control over data management, technical assistance and funding. A third point, deriving from the two above, is that the outward appearance of simplicity of the BFP's mechanisms belies its inchoate inner complexities, and the range of its influences. Such influences include its use for Roussef's political survival and as a means under Temer of tempering the enjoyment of full citizenship rights of the most destitute citizens. BFP's ubiquity may have made it as easy to publicise and to export but this has in turn weakened 
its durability. If BFP lacks institutional resilience at home, on what grounds can it be proffered to other developing world states acting on it as a model?

In the Philippine case, Pantawid appears at a gloss to be social protection's lucky adoptee. It emerged relatively quickly, such that even four years after implementation when it accounted for over half of the DSWD budget not much publicly available data existed. By 2011, it was instituted nation-wide, and by 2014 reached over 4 million beneficiary families (Swamy 2016), a remarkable achievement. However, problem areas have been elided or amplified depending on who conducts or reports the inquiry, and for what purposes.

Acosta and Velarde (2015) attribute Pantawid as a factor in reducing absolute poverty in a cost-effective, well targeted delivery system. Their ideas on improvements include adjusting the benefits level and making coverage sustainable. However, they do not acknowledge long-standing allegations by regional political voices of undelivered benefits, ghost beneficiaries, unmet conditionalities, and untouched Pantawid bank accounts. As much as PHP 6.3 billion of Pantawid transfer cash remained unliquidated by 2017 (Diaz 2017, September 2). Regardless of the respective CCTs' real or promoted accomplishments, neither BFP or Pantawid generated unchallengeable support for their political champions. This mirrors the institutional 'skin' of the Brazilian CCT case.

A second issue relating to timing and sequencing concerns the leadership of the DSWD. Yusuke Takagi (2017) demonstrates that the Aquino administration of 2010 to 2016 was more successful in broad-based social policy reform than weak state theory would have anticipated. Under Aquino, a broad-based social policy agenda incorporated reproductive health, a 'sin tax' on tobacco, and primary level education for all as well as a rapid, nation-wide expansion of the Pantawid programme. Reform policy of this kind is unprecedented in the Philippines. The reason for its success was that capable and ambitious political actors could create linkages between business sector interests, existing political structures, and social reform advocates to produce coalitions for action that transcended clientelistic norms. Examples of such actors include Corazon Soliman, who was selected by Aquino as secretary of DSWD for the full term of his presidency despite her participation in Gloria Arroyo's first government. Soliman had sole, independent control over the widening and deepening of Pantawid, added to which her longevity in the role meant that the Pantawid drive was relatively freed of subordinating and predatory strategies by competing Departments and patronage interests. Soliman's achievement with Pantawid is compelling because it required a constant hand on the tiller to resist varieties of institutional capture. Timing, sequencing and leadership as factors in the contestation of weak state theory thus call for further analysis beyond the scope of this paper.

A sea change in the status of DSWD and Pantawid took place with the 
election of Rodrigo Duterte in the May 2016 elections. Having campaigned on extending the Pantawid programme to include extra rice distribution (Macas 2016), Duterte first appointed Judy Taguiwalo, one of four National Democratic Front members in the cabinet, to head DSWD. Ideologically, the National Front bloc opposed Arroyo-Aquino policies and never formerly endorsed any aspect of Pantawid. They intended to direct social protection towards jobs creation, agrarian reform and national industrial development projects (Sauler 2016). Taguiwalo had therefore originally planned to review and revise Pantawid but largely maintained the existing programme during the 13 months of her tenure (Sy 2017). However, on August 16, 2017 the Philippine Commission on Appointments voted against her continuation as cabinet secretary on several undisclosed grounds. Unofficially, problems incuded her resistance to the use of DSWD funds in patronage 'pork barrel' politics, her leftist credentials, her non-conformity with tax reform policy, allegations of Pantawid funds being redirected to the New People's Army, and her opposition to legislating the criminalisation of minors (Sy 2017, August 17; Romero 2017, August 28). President Duterte provided her with no statement or show of support. As Walden Bello (2017) notes, the only evidence of any actual political policy under Duterte is 'mass murder'. The number of civilians killed and assessed as official or unexplained deaths under the authorisation of the current administration is above 14, 000 (Baldwin and Marshall 2017, June 25).

Taguiwalo's successor at DSWD since August 19, 2017 is Emmanuel Leyco, a professor of asset backed securities analysis, credit rating, and project financing. He specialises in health care financing in association with MLOs such as ADB and US AID (Asian Insitute of Management 2017). Within 18 months the DSWD has thus been passed from Soliman, a social work and administration specialist, to Taguiwalo, a leftist academic and activist, to Leyco, a neoliberal finance technocrat for whom sustainable development is conceivably inalienable from venture capitalism. These are seismic shifts with serious implications for the security, purposiveness and resilience of Pantawid as an institution. To interpret such shifts, we need to return to an earlier point about constitutional and rights-based groundings for social protection.

A substantial difference between CCTs in Brazil and the Philippines is that constitutionally guaranteed citizenship rights play no special part in the ideas behind the design and implementation of Pantawid. The programme is a collective action response to the practical issues of post-2007 MDG compliance, internal institutional reform, developmental slipstreaming, and a mutually beneficial opportunity regarding World Bank prerogatives in global social protection. In other words, throughout the benign years of the Aquino administration, the poorest deciles occur as a placeholder for institutional dynamics with many moving parts. As Mark Thompson (2016) argues, now that Duterte's objective is to lay waste 
to liberal democratic institutions, the 'poverty' placeholder serves a different purpose: the poor exist to be liberated of their livelihoods and their lives with equal disregard.

Given such conditions, what can the purpose of a public sector financial engineer like Emmanuel Leyco be for the DSWD? Speculatively, the ADB, the World Bank and US AID, among the list of IFI/MLO donor/lenders to the DSWD's programmes, would favour an experienced institutional insider to safeguard their interests. Potentially, the macro-political chaos of Duterte's anti-social assassination campaign provides cover to enclose social protection in ever-stronger neoliberal market relations: e.g. venture capital in schools and clinics. Meanwhile, politicians invested in the pork barrel uses of departmental budgets have positioned themselves for years to take advantage of institutional uncertainty. Bong Bong Marcos, a Philippine senator and son of the former dictator, has argued in bad faith since 2014 that Pantawid showed no evidence of achieving its goals, lacked transparency, and failed the poor (Mendez 2014). Should he run for the presidential office in 2022 or succeed the current vice-president, Leni Robredo, for which end he has been using the courts under allegations of electoral fraud, Pantawid in its current form could be quickly scaled down or abolished. Indeed, stripping Pantawid of institutional resilience would suit the purposes of many political insiders. Arun Swamy's (2016) idea of Pantawid's targeting system serving as a means of keeping social protection free of patronage is therefore at risk. A reversion to discretionary allocations of and clientelistic influence over social protection funds is a possibility that observers must pay close attention to, to which end close monitoring of the forthcoming local ('barangay') elections of 2018 is important.

Since the Philippines is not an exporter of CCTs, Pantawid's crossinstitutional dynamics are restricted to the two domestic actors we have considered: IFI/MLO donor-lenders and political actors with interests in DSWD's programmes. A third domestic factor is Pantawid's array of embedded links to and within separate state structures. These include the departments of Health, Education, Labour and Employment, Interior and Local Government, Budget and Management, the National Nutrition Council, the National Commission on Indigenous Peoples, Philippine Commission on Women; the National AntiPoverty Commission, the National Economic Development Authority, and the Commission on Population. These entanglements require a separate study but it suffices to state that problems of co-ordination and communication accrue. In other words, for CCTs institutional boundedness involves space and distance from competing interests.

At the 'within-institution' level, the DSWD embarked on a reform process in 2007 to complement the implementation of 4Ps/Pantawid to the department's mandate. Within three years, however, the CCT programme dominated the 
DSWD's functions and profile. Evidence of this evolution as a problem can be seen in the following example. Reyes (2017) reports on DSWD's failures to fulfill public welfare obligations following the devastation of Typhoon Yolanda in 2013, despite millions of dollars of charitable aid and donations remaining unliquidated in DSWD accounts. Institutional prowess in one capacity offset by institutional incompetence in another creates structural and reputational damage to the entire system, thereby diminishing its resilience in the event of political shocks.

For CCTs in Brazil and the Philippines, the primary shock to their respective resilience was political change in 2016. Each programme grew at pace from early-stage implementation to dominate the respective social protection arena. This, however, marked them out as target victims of their real or promoted success: speedy widening and deepening did not allow for relative structural insulation from policy shocks, and at the 'within-institutional' level ideological, core competency and political distortions contributed to systemic stress.

Nevertheless, it is important to note that there has been a differential impact on social protection of rapid political change in Brazil and the Philippines. While Brazil's President Temer vowed immediately on assumption of office to draw down BFP's reach and leverage, the Philippine case is more ambivalent. President Duterte had promised to extend the nutritional aspects of Pantawid prior to the elections but then failed to support his own nominee for DSWD secretary at her 2017 confirmation hearing. Duterte's campaign of mass murder against the poor under a 'war on drugs' rubric contrasts awkwardly with his appointment of a orthodox neoliberal to succeed Taguiwalo as DSWD secretary. Such erratic conditions within and surrounding the DSWD favor predatory opportunism and a reversion to institutional capture under patronage powers. However, it is unlikely that an aggressive assault on Pantawid-such as evidenced by Temer's treatment of BFP-could occur without further seismic political shifts, such as a second Marcos presidency.

We can furthermore observe that elite opportunism regarding CCTs differs. In Brazil, Temer's cabinet disavows public expenditures on the poorest deciles for an array of reasons, not excluding issues of class, race and social standing. Indeed, hardening race/class/gender cleavages appears to be an explicit objective of policy. In the Philippines, as Swamy (2016) notes, social protection has traditionally been the preserve of patronage politics. Ways of reincorporating Pantawid and DSWD within such embraces occurs as a matter of timing, sequencing and preparation, as Senator Marcos's criticisms from 2014 can more fully be understood. Although the elite, male, right-wing parliamentary coup in Brazil contrasts fundamentally with the electoral victory of a neo-authoritarian populist with a social cleansing agenda in the Philippines, institutional social protection in both cases is a clear target for reabsorption into existing neoliberal 
and top-down, elite-driven stratagems.

In Brazil, Temer's austerity measures against BFP deflect attention from an explicit two-fold agenda. A first priority is to cover and recover from astronomical levels of corruption characterised by the evolution of grand vanity projects like the Olympics and the World Cup, and in part to reconcile budget deficits by suppressing social expenditure. A second priority involves giveaways to political coalitions in agri-business, mining, and logging. Fragmenting social movements and maintaining pressure of various kinds on the poor acts as a front and an enabling device for such elite-level policy ties.

In the Philippines, Pantawid is in a more erratic condition. Over the past 14 months, additional conditionalities as well as a new rice subsidy measure on the beneficiary side of the equation contrast with extreme shifts in direction to the hard left and thence without notice to the neoliberal right. These shifts are not evidently reforms of a smokescreen or punchbag nature. They occur more as fluctuating manifestations of the brute force power politics that Duterte has come to personify within his first year of office.

\section{CONCLUSION}

This paper has traced the processes in social protection evolution in Brazil and the Philippines that led to the need for and implementation of CCTs, and comparatively examined the way these CCTs work with respect to the timing and sequencing of events that led to major electoral and policy shocks since 2016. We have also considered factors at the within- and cross-institutional level that contribute to varying degrees of systemic resilience.

Discussion and analysis have moreover considered the within- and cross-institutional boundedness of CCTs and the extent to which their potential for resilience can be anticipated. BFP's relative institutional independence, its focal centrality, and its real roots in a major political party of nationwide offer it advantages for survival and future development. To what extent it can tap into and drive community and citizenship values as Adesina (2010) and Lomelí (2008) conceptualise the intrinsic value of CCTs remains to be seen.

Nevertheless, BFP's potentials contrast with Pantawid's varieties of limitations: it does not have the support of the National Front, the largest grassroots social movement in the country and it is framed as the vehicle of a liberal, one-term president. Furthermore, its tasks remain within the purview of the DSWD, a department with multiple separate responsibilities, hedged in its powers by close structural association with competing cross-instituutional departments. The danger, under this analysis, is that CCTs will cede ground to non- and anti-democratic stratagems or be unable to resist incorporation into overtly asymmetrical state relations vis-a-vís the needs of the poor. The question 
of institutional durability for CCTs in middle-income developing countries like Brazil and the Philippines under seismic political shifts is thus critical.

Brazil exhibits a number of elements that provide BFP with high chances of survival and restoration. It has a long history of organised ideological opposition, a variety of successful social movements, a recent experience of constitution- and rights-based social policy, and over a decade of electoral power in the hands of the nominally pro-poor Workers' Party. In addition, BFP operated as an original initiative of real influence at home and abroad for 13 years. BFP's use as an electoral card and its importance to some 25 percent of the population may resurrect its institutional value in the elections anticipated in 2018.

In the Philippines, elite capture has resulted in weak to meaningless party politics, a legacy of elites-only political power, the intractability of the pork barrel, and the use of institutions like social protection as functions of patronage politics. Pantawid as an imported model and shepherded to nation-wide rollout by Begnino Aquino, whose ostensible popularity and liberal policies have suffered drastically in the light of the extraordinary emergence of Rodrigo Duterte, did not have time to become rooted into the popular consciousness as its implementers had no doubt intended. This CCT will likely forego the potential to offer the poorest citizens developmental opportunities that are unhinged to clientelist relations and neoliberal structures of dominance. Instead, Pantawid may over time become absorbed into the tissue of everyday political norms framed within domestic traditions and culture. Timberman (2015) has demonstrated in a separate area of analysis how a deep conservatism appears reliably and effortlessly to be hard-wired into the country's culture of expectations. It should therefore not be imagined that the current culture of authorised mass murder and the despoiling of liberal democratic institutions will be overturned by 2022 , the earliest date for presidential elections, a waiting period aggravated by the potential for the 2018 local elections to be usurped.

Neither scenario is at present optimistic but the scope for more anthropological and historical research into the value and use of varieties of cash transfer as means of alleviating poverty, reducing inequalities and bolstering democracy is highly and urgently recommended. From the experience of poor countries during the SAP era, the importance of institutional resilience in social protection and the costs of failure are hard to overestimate.

\section{REFERENCES}

Acosta, Pablo and Rashiel Velarde. 2015. An Update of the Philippine Conditional Cash Transfer's Implementation Performance. Manila: The World Bank. Adesina, Jimi. 2010. "Rethinking the Social Protection Paradigm: Social Policy in Africa's Development." Promoting Resilience through Social Protection in Sub-Saharan africa, 2-22. Dakar: European Report on Development/ 
European University Institute.

Asian Institute of Management. 2017. Faculty - Emmanuel A. Leyco. Asian Institute of Management. Retrieved October 11, 2017. http://wsgsb.aim.edu/facultylist/faculty-emmanuel-a-leyco

Assunção, Juliano. 2006. Land Reform and Landholdings in Brazil. Helsinki: United Nations University-World Insitute for Development Economics Research.

Balamban, Bernadette, Mildred Addawe, and Mary Darunday. "Official Poverty Statistics and Poverty Reduction Programs of the Philippines." Paper for the International Conference Workshop on Poverty and Inequality in Asia, Bali. May 7-9, 2013.

Baldwin, Clare and Andrew Marshall. "More blood but no victory as Philippine drug war marks its first year." Reuters. June 25, 2017. Retrieved June 30, 2017.

Bello, Walden. 2009. The Anti-Development State: the political economy of permanent crisis in the Philippines. Manila: Anvil.

Bello, Walden. "Why it's time for progressives in the Duterte Cabinet to leave." Rappler. August 20, 2017. Retrieved September 9, 2017.

Bourguignon, Francois, Francisco Ferreira and Phillipe Leite. 2003. "Conditional Cash Transfers, Schooling, and Child Labor: Micro-Simulating Brazil's Bolsa Escola Program." The World Bank Economic Review 17(2): 229-254.

Bradshaw, Sarah. 2008a. "From structural adjustment to social adjustment: A gendered analysis of conditional cash transfer programmes in Mexico and Nicaragua." Global Social Policy 8(2): 188-207.

Bradshaw, Sarah. 2008b. "An Unholy Trinity: The Church, the State, the Banks and the Challenges for Women Mobilising for Change in Nicaragua." Institute for Development Studies Bulletin 39(6): 67-74.

Branco, Mariana. "Brazil: over a million irregular cases found in Bolsa Família program." Agencia Brasil. November 11, 2016.

Britto, Tatiano. 2005. Recent trends in the development agenda of Latin America: An analysis of conditional cash transfers. Brasília: Ministry of Social Development.

Campbell, Alan T. "Land grab in Amazon jungle threatens dispossession, violence and murder." Guardian. September 10, 2017.

Cookson, Tara P. 2016. "Working for Inclusion? Conditional Cash Transfers, Rural Women, and the Reproduction of Inequality." Antipode 48(5): 1187-1205.

Curry, Mark. 2014. "Patchwork vs Proactive Social Protection Policies: CCTs and Social Expenditures in Brazil and the Philippines." (Asian) International Studies Review 15(2): 25-48.

Curry, Airah Cadiogan, and Rogerio Giugliano. 2013. "Brazil's Bolsa Familia and the Philippines' '4Ps' CCT Programs: South-South Cooperation for Social 
Policy Formulation and Poverty Reduction." Asia Pacific Social Science Review 13(1): 1-15.

Department of Social Welfare and Development. 2013. Updates on Reform Agenda Milestones. Policy Development and Planning Bureau. Quezon

City: Department of Social Welfare and Development (DSWD).

Department of Social Welfare and Development of the Philippines. 2009.

Conditional Cash Transfer (CCT) Philippines - Improving the Human Capital of the Poor (Pantawid Pamilyang Pilipino Program or 4Ps). 4Ps Concept Paper for MCC.

Diaz, Jess. "Lawmaker exposes 466,000 ghost CCT beneficiaries." Philippine Star. September 2, 2017.

Economist. "Dilma announces rise in Bolsa Família poverty transfers." Economist. May 4, 2016.

Engracia, Sylvia. 2015. Philippines: Strengthened Gender Impacts of Social Protection. Quezon City: Asian Development Bank.

Fernandez, Luisa and Rosechin Olfindo. 2011. Overview of the Philippines' conditional cash transfer program: The Pantawid Pamilya Pilipino Program (Pantawid Pamilya). Manila: The World Bank Office Manila.

Fiszbein, Ariel and Norbert Schady. 2009. Conditional Cash Transfers: Reducing Present and Future Poverty. Washington, D.C.: The World Bank.

Fukuda-Parr, Sakiko, Alicia Yamin and Joshua Greenstein. 2014. "The Power of Numbers: A Critical Review of MDG Targets for Human Development and Human Rights." Journal of Human Development and Capabilities 15(2-3): 105-117.

Haggard, Stephen and Robert Kaufman. 2008. Development, Democracy, and Welfare States. Princeton: Princeton University Press.

Hall, Anthony. 2007. "Social policies at the World Bank: paradigms and challenges." Global Social Policy 7(2): 151-175.

Hall, Anthony. 2008. "Brazil's Bolsa Familia: A double-edged sword?." Development and Change 39(5): 799-822.

Hunter, Wendy and Timothy Power. 2005. "Lula's Brazil at Midterm." Journal of Democracy 16(3): 127-139.

Levitsky, Steven and Lucan Way. 2015. "Not just what, but when (and how): comparative-historical approaches to authoritarian durability." In Advances in Comparative-Historical Analysis edited by James Mahoney and Kathleen Thelan, 97-120. Cambridge: Cambridge University Press.

Lomelí, Enrique. 2008. "Conditional Cash Transfers as Social Policy in Latin America: An Assessment of their Contributions and Limitations." Annual Review of Sociology, 34(1): 475-499.

Macas, Trisha. 2016. To expand 4Ps, Duterte promises to give a sack of rice to poor families. Manila: GMA News. 
Mahoney, James and Kathleen Thelen. 2015. Advances in Comparative-Historical Analysis. Cambridge: Cambridge University Press.

Mendez, Christina. "Marcos: Aquino's CCT a failure." Philippine Star. August 6, 2014.

Mkandawire, Thandika. 2001. Social Policy in a Development Context. New York: The United Nations. New York: United Nations Research Institute for Social Development.

Molyneaux, Maxine. 2006. "Mothers at the Service of the New Poverty Agenda: Progresa/Oportunidades, Mexico's Conditional Transfer Programme." Social Policy \& Administration 40(4): 425-449.

Philippines Department of Budget and Management. 2016. National Expenditure Program 2016 XX DSWD. Retrieved May 7, 2017. www.dbm.gov.ph

Phillips, Dom. "Brazil senate approves austerity package to freeze social spending for 20 years." Guardian. December 13, 2016. Retrieved September 7, 2017.

Reid, Ben. 2016. "The geopolitical economy of social policy in the Philippines: securitisation, emerging powers and multilateral policies." Third World Quarterly 37(1): 96-118.

Reyes, Celia and Aubrey Tabuga. 2012. Conditional Cash Transfer Program in the Philippines: Is It Reaching the Extremely Poor. Manila: Philippine Institute for Development Studies.

Reyes, Mary Ann. "Hidden Agenda: Tough Job." Philippine Star. August 27, 2017. Retrieved September 9, 2017. http://www.philstar.com/business/2017/ 08/27/1732967/tough-job

Romero, Alexis. "Duterte: There were reports CCT funds went to NPAs." Philippine Star. August 28, 2017. Retrieved November 20, 2017.

Sauler, Erika. "Anti-poverty official seeks review of 4 Ps." Philippine Inquirer. July 14, 2016. Retrieved September 5, 2017.

Silva, Maria O. 2014. The Conditionalities of the Bolsa Familia: its conservative face and limitations to implement the Citizenship Basic Income in Brazil. Montreal: BIEN.

Soares, Sergio. 2012. Bolsa Familia, its Design, its Impacts and Possibilities for the Future. Brasilia: International Policy Centre for Inclusive Growth (IPC-IG) UNDP.

Swamy, Arun. 2016. "Can Social Protection Weaken Clientelism?: Considering Conditional Cash Transfers as Political Reform in the Philippines." Journal of Current Southeast Asian Affairs 35: 59-90.

Sy, Marvin. "Taguiwalo Rejected as DSWD Chief." Philippine Star. August 17, 2017.

Tabor, Steven. 2002. Assisting the Poor with Cash: Design and Implementation of Social Transfer Programs. Washington: The World Bank.

Takagi, Yusuke. 2017. "Policy coalitions and ambitious politicians: a case study 
of Philippine social policy reform." Philippine Political Science Journal 38(1): 28-47.

Thompson, Mark. 2016. "Bloodied Democracy: Duterte and the Death of Liberal Reformism in the Philippines." Journal of Current Southeast Asian Affairs 35(3): 39-68.

Timberman, David. 2015. A Changeless Land. New York: Routledge.

United Nations Development Programme. 2015. United Nations Development Report 2015: Work for Human Development. New York: UNDP.

United Nations Development Programme. 2013. The Rise of the South: Human Progress in a Diverse World. New York: UNDP.

Williamson, John. 1993. "Democracy and the "Washington Consensus"." World Development 21(8): 1329-1336.

World Bank. 2016. "CCT Programs: Now on Every Continent." The World Bank: Research at the World Bank. Retrieved September 16, 2017. http://go. worldbank.org/K38KR408E0 